\title{
Legislative Review, New Directions and Refugee Resettlement
}

\author{
Michael Casasola
}

\begin{abstract}
On the surface the proposals surrounding refugee resettlement in the 1999 "white paper" Building on a Strong Foundation for the 21st Century: New Directions for Immigration and Refugee Policy and Legislation appear to be watered down versions of Legislative Review Advisory Group (LRAG) 1998 report Not Just Numbers: A Canadian Framework for Future Immigration proposals. However, the "white paper" proposals are the "tip of the iceberg" of a series of recommendations Citizenship and Immigration Canada (CIC) has developed on how Canada should resettle refugees in the future. This paper outlines and compares the LRAG report, the "white paper" and CIC's model for future resettlement. It argues that the proposals offer an opportunity to diminish long-standing barriers to the Canadian resettlement program, though the motivation for these changes may be partially based on very practical operational needs. Yet in order toensure such change takes place, NGOs will have to continue to pressure $\mathrm{CIC}$ and the Minister of Citizenship and Immigration that Canada's resettlement program be truly humanitarian and that the number of refugees resettled each year not be reduced.
\end{abstract}

\section{Précis}

En surface, les propositions concernant la relocalisation des réfugiés dans le «livre blanc» de 1999 De solides assises pour le $21^{\mathrm{e}}$ siècle: Nouvelles orientations pour la politique et la législation relatives aux immigrants et aux

Michael Casasola is the Director of the R.C. Diocese of London Refugee Office and has managed refugee sponsorship for the Diocese for eight years. He is actively involved nationally and internationally in refugee resettlement policy development, and has participated in both the LRAG and RRM consultations. réfugiés apparaissent comme une version édulcorée du rapport Au-delà des chiffres: L'immigration de demain au Canada, ayant émané du Groupe Consultatifen 1998. Cependant, les propositions du "livre blanc» ne sont que la pointe de l'iceberg d'une série de recommandations développées par Citoyennetéet Immigration Canada sur la façon dont le Canada devrait désormais relocaliser les réfugiés. Le présent article décrit et compare le rapport du Groupe Consultatif, le «livre blanc», et le modèle proposé par Citoyenneté et Immigration Canada. On développe ici une argumentation selon laquelle toutes ces propositions offrent une opportunité de réduire les vieilles barrières entravant le programme canadien de relocalisation, malgré le fait que les motifs suscitant ces changements sont probablement en bonne partie fondés sur des besoins opérationnels et pratico-pratiques. Cependant pours'assurer que ces changements sont effectivement mis en place, les $O N G$ vont devoir continuer d'exercer leurs pressions sur Citoyenneté et Immigration Canada et sur le Ministère de la Citoyennetéet del'Immigration pourque le programme canadien de relocalisation maintienne sa perspective humanitaire, et pour que le nombre de réfugiés relocalisés n'aille pas en s'amenuisant.

The proposals regarding refugee resettlement within the Legislative Review Advisory Group (LRAG) 1998 report Not Just Numbers: A Canadian Framework for Future Immigration werethe source of initial excitement. The report seemed to recognize what NGOshad been saying for years, that legislative barriers were undermining the effectiveness of Canada's refugee resettlement program as a tool of protection. However, the framework proposed by the Advisory Group was ambiguous and actually risked undermining resettlement through the introduction of new barriers.
The recommendations concerning resettlement in Citizenship and Immigration Canada's (CIC) 1999 "white paper" Building on a Strong Foundation for the 21st Century: New Directions for Immigration and Refugee Policy and Legislation are also exciting, yet equally ambiguous. On the surface they appear to be watered down versions of LRAG proposals. Tounderstand them better, however, one should look not at the LRAG report, butatCIC's own Refugee Resettlement Model (RRM). This model, developed by CIC for the most part independent of the LRAG process, has notbeen somuch in response to the principles laid out in the LRAG report, but in response to practical political imperative and departmental needs. This model is superior to the LRAG framework in that it is more likely to be implemented and addresses some of the weaknesses in the Canadian system identified by the LRAG without introducing new barriers. Nevertheless, the ambiguity of New Directions and the fact that the RRMcontinues to evolve underlines the importance for NGOs to continue to urge the Minister and CIC to lower barriers without reducing Canada's resettlement levels.

\section{The Current Canadian Resettlement System}

Historically refugee resettlement has been one of the most important ways Canada has contributed to international responsibility-sharing for the world refugee crisis. Over time, large numbers of refugees have been resettled in Canada. In fact, Canada is one of very few states which routinely provides resettlement opportunities. ${ }^{1}$ Despite the value of this solution, fewer refugees have been coming to Canada throughits resettlement programs in recent years. Throughout the 1980s Canada averaged annual resettlement levels (all programs) of $21,000 .^{2}$ For 1998 the government projects arrivals of resettled 
refugees at 9,500. The estimates for the number of refugees Canada plans to resettle in 1999 are 10,100-11,300 $(7,300$ government-assisted refugees and $2,800-4,000$ privately sponsored).

The PrivateSponsorship of Refugees Program in particular has suffered a serious downfall. Private sponsorship levels have declined from an average of 9,000 peryear in the 1980 s, to the current low of below 2,200. This decline has been due in part to high refusal rates, slow processing of cases overseas and problems in communication. ${ }^{3}$

For a refugee to be selected by Canada for resettlement, she must not only satisfy a Canadian visa officer that she is a Convention Refugee or a member of a Humanitarian Designated Class, ${ }^{4}$ but that she has the "ability to successfully establish" herself in Canada. This seemingly objective assessment essentially measures the ability to become financially independent within one year of her arrival. ${ }^{5}$ In reality this is a highly subjective assessment which has led to inconsistent decision-making among visa posts. This criterion can prevent Canada from resettling refugees believed to be in greatestneed of protection or a durable solution.

Another shortcoming has been slow processing of applications. This reality has meant that, barring exceptional cases when a Minister's Permit is used, Canada is unable to assist those in urgent need of protection. While other countries can movea refugee out of danger within 24 hours, Canada must first complete criminal, security and medical checks. Furthermore, refugees are affected by Canada's medical admissibility criterion. This criterion bars from Canada all those with a contagious disease as well as those who have either a medical disability or require treatment viewed as "excessively costly" on the Canadian health care system, even if they have been identified by UNHCR as refugees in need of resettlement.

These barriers prevent Canada from responding to those refugees in greatest need -either most vulnerable or those in imminent danger. Instead, Canada responds best to those refugees needing resettlement who are near Canadian embassies or are in stationary camplike situations. The fact that there are more visa officers in Europe partially explains why Canada has tended to select a higher percentage of refugees in Europe. This is in greater proportion to the resettlement need identified by UNHCR in that region. Areas like Africa and the Middle East have proportionally fewer Canadian visa officers in comparison to the resettlement needs identified by the UNHCR. ${ }^{6}$

This phenomenon is magnified by the reality that in the age of Canadian budget cutting, there are fewer and fewer visa posts offering immigration processing, fewer visa officers overall and an emphasis in immigration processing of minimizing the direct involvement of visa officers. This approach contrasts with refugee processing which requires relatively more time and resources because of the need for interviews and area missions. ${ }^{7}$

\section{Not Just Numbers (LRAG) Proposals}

The LRAG response proposed a new system which combined the inland and overseas systems and emphasized protection at first opportunity. The report's novelty and significance was that it acknowledged the barriers that NGOshad long identified as undermining Canada's resettlement program.

Our current resettlement from abroad program, established under the Immigration Act, is designed to select persons who both require protection and are able to demonstrate thebasic skills to settle successfully in Canada. Thus, our requirements sometimes deny us the very tools we require to select those in greatest need, by screening them out. ${ }^{8}$

While immigrants should be selected according to Canada's needs, the report argued, refugees should be selected solely in response to their protection needs, whether inland or overseas. The report expressed a preference for providing protection at first opportunity, meaning overseas, rather than responding to their protection needs at Canada's borders. It emphasized protecting the most vulnerable and those moot in need. However, it also proposed erecting new obstacles that undermine these goals through the introduction of admission ceilings and tying the overseas systems resources to the inland system.

\section{LRAG Highlights Relating to Refugee Resettlement:}

- Protection Act (separate from a Citizenship and Immigration Act).

- Prioritizing the most needy and most vulnerable at first opportunity.

- Selection decisions will be made by a new decision-making body, a Protection Agency, composed of protection officers, career civil servants independent of Citizenship and Immigration.

- Protection Officers are to be highly trained on international humanitarian and human rights obligations, judicial procedure and to rotate postings in Canada and overseas.

- NGOs could be contracted by the Protection Agency to undertake refugee selection.

- Not all refugee applicants may be interviewed; paper screening could be used.

- Refugees in immediate need of protection could be moved immediately to Canada under a Temporary Protected Status upon which time their landing will be finalized.

- Refugees must still pay the Right of Landing Fee. Aloan program would be available.

- Refugees will no longer be assessed on their ability to successfully establish in Canada.

- Persons granted protection and their dependants will be exempted from the excessive cost component of the medical inadmissibility provisions.

- No appeal (can seek leave to review at Federal Court).

- Counsel will be permitted (at the applicant's expense) to attend interviews.

- Organizations will be able to enter into agreements with the Protection Agency to sponsor persons in need of protection.

Probably more than any other area of the LRAG report, the Advisory Group's 
resettlementmodel is unclear and undefined, making it from the outset unlikely to be implemented. The report introduced ideals of assisting "the most vulnerable and most in need" without defining whom they mean. The emphasis on resettlement at first opportunity is also ambiguous. It doesnotexplain how providing resettlement at first opportunity can be provided in the context of resettlement, whether it simply means that resettlement is preferred to asylum, that processing overseas should be expedited, or that resettlement efforts should be concentrated in or around source countries.

The report envisioned a new role for NGOs. It recommends contracting NGOs to select refugees in some areas. NGOs had a number of obvious concerns about the proposed change of their role from advocates and service providers to implementing Canadian policy in refugee selection.

While there a number of merits in the proposed LRAG framework, it also included measures which could reduce the number of refugees Canada resettles. The report proposes to set limits on the annual numbers of refugees to be resettled from abroad, effectively undermining the voluntary sector's contribution. This would mean the more that private groups sponsor, the fewer the government may resettle-thus undermining a significant portion of the voluntary sector's interest in assisting in resettlement.

The LRAG reportalso made possible the reduction of resettlement numbers through the linking of resources between the inland and overseas systems. LRAG proposed that the two systems be linked and that the federal government be responsible for the entire cost of refugees selected in Canada. The reality that the numbers entering via the inland system are unpredictable and that resources would always be prioritized for the inland program since it is based on an international obligation, means that the resettlement program could be subject to serious funding fluctuations if the inland system were to experience even simple problems like processing delays. This model would make Canadian re- settlement levels unpredictable contrary to UNHCR guidelines. ${ }^{9}$

Currently, some resettlement countries are threatening tolinkresettlement with asylum costs by reducing their resettlement programs in response to increased cost to their inland processes. Switzerland has put this approach into effect and has apparently eliminated its resettlement program for 1998 because of increased costs in its asylum system. Without clearly saying so, the LRAG report would have had Canadajoin this trend.

Overall, the LRAG report cites the seemingly higher principles of assisting those in "greatest need" overseas, while at the same time creating a funding approach which would make doing so more difficult.

\section{Building a Strong Foundation for the 21st Century: New Directions for Immigration and Refugee Policy and Legislation}

New Directions says very little about resettlement. Nevertheless, it recognizes some of the barriers identified by LRAG and makes a commitment to strengthen resettlement and address the barriers through examples of some new measures. It proposes "A more responsive overseas resettlement program." ${ }^{10}$ Specifically,

It is proposed that Canada's refugee resettlement program bemade more responsive through such measures as:

- shifting the balance toward protection rather than the ability to settle successfully in selecting refugees;

- establishing procedures that will allow members of an extended refugee family to be processed together overseas and, where this is not possible, providing a mechanism for the speedy reunion of families;

- working more closely with non-governmental organizations in identifying, pre-screening and resettling refugees; and

- ensuring the immediate entry into Canada of urgent protection cases. 11

New Directions is ambiguous. It is unclear whether it proposes legislative, regulatory or policy changes. The recommendations reflect certain themes from the LRAG report, including an emphasis on protection, working in partnership with NGOs and responding immediately to urgent protection cases. Like LRAG, it also recommends requiring leave to appeal to the Federal Court in a resettlement case.

It does respond to an issue of concern for NGOs, not mentioned in LRAG, by offering to assist refugees' extended family members. For years refugee family members, particularly elderly, have been caught between the resettlement and the family reunification program, often not eligible for either, despite the recognition that family reunification is one of the criteria set out by UNHCR as abasis for resettlement. ${ }^{12}$ This proposal presents the opportunity to begin to address this long standing problem.

The inclusion of a proposal concerning refugee family reunification demonstrates that other factors influenced the framing of New Directions outside of the LRAG report. Certainly the public consultations played a role. Nevertheless, to better understand the recommendations in New Directions, one should consultCIC's Refugee Resettlement Model.

\section{Refugee Resettlement Model}

While LRAG provides a legislative framework, the RRM is an operational model which includes legislative, regulatory and policy proposals. It is a model which attempts to bring together both policy and operational processes. For CIC it is an operational paradigm shift. Instead of approaching the various tasks concerning resettlement in isolation, the RRM looks at refugee resettlement as an integrated continuum through the six components of identification, locating, selection, destining, orienting and finally settling in Canada. Unlike the LRAG report, which focuses on overall principles, the RRM builds on the status quo and focuses its efforts on operational issues such as effectiveness and preparedness.

The model has been developed by CIC along with operational partners over the past year. However, to date it has been as much process as product. It is not yet fully defined, though much of the direction was developed during a 
March 1998 consultation. The process has also included the establishment of a number of Working Groups, which bring together the views of all the actors involved in delivering all aspects of resettlement, including partners like NGOs and UNHCR.

As far as concrete proposals, the RRM involves a whole series of recommendations for each of the six identified points on the resettlement continuum. Some are minor changes while others are more substantive. Emphasis is on concrete, practical proposals feasible within budgetary constraints. The recommendations are still being honed and a critical path is being developed. Nevertheless, some overall themeshave surfaced. In keeping with the model's approach to resettlement as a continuum, there are overall objectives of improved communication and feedback along the continuum responding tobasic information needssuch as identifying emerging refugee populations and feedback on the settlement of refugees in Canada. Training is another issue for visa officers as well as operational partners. In addition, the model seeks to strengthen partnerships, such as with NGOs, and to develop new operational partnerships.

The RRM model is viewed as a threeyear project with the first year to implement pilot projects. The following are just a few highlights.

\section{Some Highlights of the RRM}

- The model's focus is operational improvements.

- Built on thecurrentresettlementsystem.

- Understands resettlement as a continuum going through six stages: identification, locating, selection, destining, orienting and settling.

- Established a number of working groups (which include NGO representation) to address particular problem areas.

- Promotes communication throughout the resettlement continuum on issues such as identification of new refugee populations and settlement experience, as well as arguing the need for information management in order to prevent duplication and to ensure that the information shared is useful.

- Training is recognized as an across the board need, including visa officers, CIC in Canada and NGO partners.

- Establish a "dedicated refugee officer" visa officer or improve specializing of visa officers to work with refugee selection.

- Seeks to strengthen partnerships with NGOs both in Canada and Overseas.

- Seeks to develop overseas service partners (either a NGOor IGO) who would be responsible for identifying eligible refugee populations for resettlement and processing applications.

- Overseas pre-departure orientation to focus on orientation to Canada as opposed to language training.

- Developing blended initiativesRefugee sponsorships which are partially funded by both the government and private sponsors to respond to either resettlementemergencies or refugees who do not meet current Canadian criteria.

- Establish a New Zealand-style reception centre(s) capacity for refugee Women at Risk resettled to Canada on an emergency basis.

- Goal for refugee is independence which is measured on sliding scales concerning the following components: orientation, language skills, employment, family reunification, security/stability.

The RRM was initiated in response to the resettlement "crisis" CIC experienced in the summer of 1997. At that time it appeared that CIC would actually not be able to achieve its resettlement targets-that it would not be able to "find" 7,300 refugees that were eligible and admissible. The Minister of Citizenship and Immigration's apparent unwillingness to seenumbers decrease forced the department to scramble in order to meet the required targets. This experience and the fear that it may be repeated in subsequentyears suggested the need to begin long term planning on how it will select refugees in the future.
This planning recognizes that this problem was likely to be only compounded in coming years as fewer refugees from Bosnia were likely to need resettlement and that Canada would have to discover and identify new populations which need resettlement and meet $\mathrm{Ca}$ nadian criteria. At the same time, UNHCR, the organization most likely to be able to help Canada identify potential refugees for resettlement, faces its own resource crunch making it more difficult for it to find the resources necessary to help Canada meet its resettlement targets. This experience led CIC to develop anew model in order to address and prepare for current and impending problem areas.

Some of the RRM recommendations appear to be watered down versions of the LRAG report. For example, instead of eliminating the "ability to successfully establish" criterion, RRM asks only to loosen the criterion. While the LRAG proposes the use of NGOs to select refugees, RRM proposes a more American Joint Voluntary Agency style model in which NGOs would identify and prepare resettlement cases for visa officers.

A strength of the RRM is its focus on problem solving. While grounded in the current resettlement approach, CIC's proposed changes also recognize that the Canadian refugee resettlement process is in a state of disrepair. CIC recognizes long standing problems such as inconsistency in the application of eligibility and admissibility criteria by visa officers. It also concedes that $\mathrm{CIC}$ is illprepared to deal with emergencies and immediate protection cases.

The RRM's willingness to move towards diminishing the importance of "ability to successfully establish" criterion is an importantbreakthrough. This measure would achieve a number of objectives. First, it affirms the humanitarian nature of Canadian resettlement. Secondly, it responds to a view within $\mathrm{CIC}$ that refugees may require longer periods of assistance. Finally, it helps CIC in responding toits overall commitment to reach established resettlement targets. 
Lowering this barrier will likely produce critics who will argue that it will lead to the admission of refugees requiring longer periods of assistance and increased demands on settlement services. Subsequently, Canada's resettlementlevels should be reduced if Canada is to continue to operate within the current budget. Ultimately, they propose that Canada's resettlement program should be driven by dollars and not by numbers.

This view must be challenged. Admitting refugees who may take longer than one year to adapt only recognizes what may already be reality and occurring within the current budget. At the same time, the argument that refugees may take longer to settle should not be accepted entirely before examining the effectiveness of Canadian settlement programs. An obvious barrier to the success of current settlement programs is the reality that CIC measures settlement by economic self-sufficiency. Yet, CIC funded programs do not include employment training.

Fortunately, to date the Minister has not pursued a dollar-driven approach and has maintained resettlement targets in spite of the interest within CIC at times to introduce a 6,800-7,300 target for yearly intake. NGOs can be heartened by the success they have achieved by encouraging the Minister to insist on maintaining current resettlement levels. This pressure is in many ways responsible for re-examining old tenets like the ability to successfully establish criterion.

Theemphasis on delivering numbers since mid-1997 has forced CIC to select from refugee populations ithad not previously considered, like Bosnian refugees in Germany. The belief that the Bosnian resettlement need is diminishing, means Canada is forced to look at new refugee populations who are less accessible and for whom ability to successfully establish has been seen as a barrier to their admission. Expecting refugees to be able to become financially independent within, for example within a three to five year time frame, instead of one year, would create the domino effect of making more refugees eligible for resettlement who were previously ineligible. This, along with the introduction of NGO partnerships overseas to help identify these refugees, solves CIC's problem of reaching its targets.

\section{Conclusion}

On the surface New Directions proposals appear to be responsive to LRAG proposals. However, it is not so much responsive to the LRAG's proposal, but more a foreshadowing of the Refugee ResettlementModel.

The goals set out in New Directions concerning resettlement are generally worthy of support. However, their ambiguity requires that they be spelled out. The RRM is the source behind the proposals, yet there is a risk that these goals may change over time if they arenotalso spelled out. As a result, with the subsequent consultation and subsequent legislative proposals, it will be important that NGOs ensure that all future proposals are developed in a way to ensure that barriers to protection are removed. The LRAG report will be a useful reference in identifying the barriers current regulations have on assisting those in need of resettlement.

Secondly, it is important to continue to keep in mind that CIC's model has been motivated by very practical concerns. Its problems achieving targets have driven a substantial part of the development of the RRM process. It is therefore important that NGOs continue to support keeping the government-assisted program level at a minimum of 7,300 persons per year. This is notmerely because of the obvious benefit for refugees needing resettlement. The reality is that CIC is being forced to look at eliminating successful establishment not simply because it is a barrier to protection, but because these requirements are inhibiting the department from finding enough admissible refugees.

It is too early to offer an endorsement of New Directions or the RRM since the outcome remains uncertain. Nevertheless, CIC's willingness to concede long standing weaknesses in the Canadian system and to develop pilotprojects and other means of addressing long term problem areas, presents opportunities to improve Canada's response to refugees. The LRAG Report, the RRM and New Directions all stress strengthening partnerships with NGOs. To date, the RRM has been responding to mainly CIC's operational needs. While some of the recommendations address some NGO concerns directly and indirectly, it will be up toNGOs to ensure that their concerns are raised and addressed as future Canadian resettlement policy develops. It is important that NGOs follow and participate in the process, not simply for the sake of the importance of their involvement, but to ensure that the final result is that Canada's refugee resettlement program is responsive, effective and truly a humanitarian program.

\section{Notes}

1. While a variety of countries have offered resettlement at various times and at varying scales, only ten countries currently commit to providing resettlement of refugees on an annual basis. They are: Australia, Canada, Denmark, Finland, The Netherlands, New Zealand, Norway, Sweden, Switzerland, United States of America.

2. Canadian Council for Refugees, Resettlement 1979-1996 Statistical Information, November 1996, 2.

3. For more on problems in the privatesponsorship program see: Non-Governmental Representatives of the NGO-Government Committee on the Private Sponsorship of Refugees, Response to the Report of the Legislative Review Advisory Group "Not Just Numbers," Ottawa, 11 March 1998.

4. Canada's Humanitarian and Designated Classes are made up of the Country of Asylum Class and the Source Country Class. For definitions see: Immigration Regulations.

5. Visa officers are supposed to balance the need for protection against the successful establishment criterion, so that the greater the need of protection, the less the establishment issue would be a barrier.

6. For more discussion see: Canadian Council for Refugees, Refugees Worldwide: Assessment of Global Resettlement Needs and Resettlement in Canada Statistical Overview 1993-1996, February 1997.

7. Canadian Council for Refugees, Issues Surrounding the Involvement of NGOs As Overseas Service Partners, September 1998, 2. 
8. Legislative Review Advisory Group, Not Just Numbers: A Canadian Framework For Future Immigration, 1998,81.

9. "UNHCR promotes with Governments the establishment of resettlement programmes which are: predictable, in terms of admissions which are: predictable, in terms of admissions diverse, in terms of the refugee beneficiaries, to include protection cases as well as refugees with special needs; responsive to emergency needs, emerging needs an appeals for burden-sharing; proactive, in addressing domestic considerations linked especially to budget constraints and problems related in integration. There is a unique challenge for Government and NGOs to listen to the local municipalities and to take listo active steps to lead, inform and assist them to make levels; and holistic, in using resettlement to ensure protection and as a lasting solution, within the context of a broader refuge policy which addresses needs in countries of origin and first asylum." UNHCR Resettlement Handbook (revised), April 1998 IIj6.

10. Citizenship and Immigration Canada, Building on a Strong Foundation for the 21st Century: New Directions for Immigration and Refugee Policy and Legislation, 1999,43.

11. Ibid., 43.

12. UNHCR, Resettlement Handbook (revised), $1 / 3$. J

\section{Refuge}

Canada's Periodical on

$$
\text { Refugees }
$$

Published six times a year by the

Centre for Refugee Studies,

York University, Toronto.

$$
\text { Available from: }
$$

Centre for Refugee Studies York University

Suite 333, York Lanes

4700 Keele St.

Toronto ON M3J 1P3

Fax: (416) 736-5843

Email: refuge@yorku.ca

http://www.yorku.ca/research/crs

\section{Asylum: \\ A Moral Dilemma \\ By W. Gunther Plaut}

Toronto: York Lanes Press, 1995

ISBN 1-55014-239-9; 192 pages, indexed; $\$ 19.90$

Every year the refugee landscape changes, but only in that more problems are added, fewer are solved, and all become constantly more urgent. Fuelled by the explosion of the world's population, the quest for asylum is one of the most pressing problems of our age. Refugee-receiving nations-located frequently, but by no means exclusively, in the Western world-have to respond to masses of humanity searching for new livable homes. Human compassion for these refugees can be found everywhere, but so can xenophobia and the desire to preserve one's nation, economic well being, and cultural integrity. The clash between these impulses represents one of the great dilemmas of our time and is the subject of Plaut's study. In exploring it, he provides a far-ranging inquiry into the human condition.

The book presents political, ethnic, philosophical, religious, and sociological arguments, and deals with some of the most troublesome and heartbreaking conflicts in the news.

Contents: The Issues; Questions Without Answers; Definitions; Religion, Natural Law, and Hospitality; A Look at History; Some Ethical Questions; Through the Lens of Sociobiology; Community and Individual; Contended Rights: To Leave, Return, Remain.

The Practice; Refugees in Africa; Four Asian Lands; Glimpses of Europe and Central America; The North American Experience; The Sanctuary Movement; A Final Look; Bibliography; Index. Asylum-A Moral Dilemma is simultaneously published in the United States by Praeger Publishers, and in Canada by York Lanes Press.

$$
\text { Available from: }
$$

Centre for Refugee Studies, York University Suite 333, York Lanes 4700 Keele Street, Toronto ON M3J 1P3

Fax: (416) 736-5837 - Email: refuge@yorku.ca 